DE
DE GRUYTER
OPEN

\title{
THE EFFECT OF EXCHANGE RATE MOVEMENTS AND ECONOMIC GROWTH ON JOB CREATION
}

\section{Chama CHIPETA*}

North-West University, South Africa

Daniel Francois MEYER

North-West University, South Africa

\section{Paul-Francois MUZINDUTSI}

University of KwaZulu Natal, South Africa

\begin{abstract}
Job creation is at the centre of economic development and remains a source of sustenance for social and human relations. The creation of a job-enabling economic environment is imperative in promoting social and economic cohesiveness in the macro and microeconomic environment. Any shocks to the economy, particularly those of exchange rate shocks and changes in economic growth, may negatively affect the labour market and job creation. This study made use of quarterly observations, from the first quarter of 1995 to the fourth quarter of 2015, to investigate the effect of the real exchange rate and economic growth on South Africa's employment status. South Africa, a developing country, was selected as a case study due to its high unemployment rate that is still increasing. The Vector Autoregressive (VAR) model and multivariate co-integration techniques were used in assessing the impact and responsiveness of employment to the real exchange rate and real economic growth in South Africa. Findings of this study revealed that employment responds positively to economic growth and negatively to the real exchange rate in the long-run. The short-run displays a positive relationship between real economic growth and employment, while the relationship between employment and the real exchange rate is also negative. However, the effect of economic growth in creating jobs is not significant enough in stimulating job creation in South Africa, as indicated by results in variance decomposition. Movements in the exchange rate exerted a significant short and long-run negative effect on employment dynamics; implying that a depreciation of the rand against the U.S. dollar is associated with decrease in overall employment. Exchange rate stability is thus important for economic growth and job creation in South Africa. The study provided further recommendations on promoting job creation in South Africa and other developing countries.
\end{abstract}

JEL classification: E65, O11, 055

Keywords: Economic Growth (GDP), Employment, Exchange Rate, Job Creation, South Africa.

* Corresponding author. Address: Vaal Campus, North-West University, South Africa, E-mail: daniel.meyer@nwu.ac.za 


\section{Introduction}

Globally, unemployment has caused negative long-run social and economic impacts affecting most developing and emerging nations (ILO, 2016). The effect of unemployment on the society and the corporate environment is such that the premise of the functioning of firms is dependent on aggregate demand assumed by the labour market and consumer demand for goods and services (Michaillat \& Saez, 2015). Thus, the displacement of workers or shocks to the labour market, particularly by price or exchange rate shocks, and any hostile changes in economic growth, may restrict consumption and cause business failures due to consumption being positively related to disposable income (Liu et al., 2015).

An economy's ability to create jobs is imperative in terms of the measurement of its macro-economic performance (Abdel-Moneim, 2015). As such, job creation remains crucial and integral to economic development and welfare (Hull, 2009). In the midst of an appropriate mobilisation of the labour market and human resources, job creation remains a key concept within spheres of corporate advancement and human development (Keller, 2015). The creation of jobs is essential for the improvement of the lives of people and the eradication of poverty (Bergh \& Zanker, 2013). Employment forms the basis on which the underpinnings of human development are shaped (UNDP, 2015). Improvements in the standards of living and quality of life thus serve as the primary objective of economic development policy (Loots, 1998). Attesting to the country's social and economic imbalances, South Africa has encountered its share of high unemployment rates (World Bank, 2016). This includes low levels of job creation and growth in the current decade, despite the inception of the 1994 social and economic transformations (Mahadea \& Simson, 2010). Disparities in the country's growth, including a depreciating and highly volatile exchange rate, have similarly proved deleterious for economic growth and employment (Rusike, 2016).

A quarterly trend analysis of the growth movements of South Africa's employment, exchange rate and gross domestic product (GDP) shows highly fluctuating trends in the country's exchange rate. Recent performance of the currency (Rand - ZAR) indicates an ongoing depreciation against the United States Dollar (USD) particularly during the 2015 to 2016 period, where the local currency depreciated to R15.98 per USD dollar in February 2016 (Deloitte, 2016). This poor performance of the local currency was associated by sluggish economic growth where real GDP slowed to 1.3 percent in 2015 compared to 2014's growth of 1.5 percent (IDC, 2016). The first quarter of 2016 reported South Africa's heightened unemployment rate of 26.7 percent (StatsSA, 2016). This instability and highly fluctuating trend resulted in low levels of job creation or employment growth.

Amongst other factors, this study focuses on GDP and the exchange rate movements affecting South Africa's level of job creation. In light of the impact of the macroeconomic setting on job creation (Gill, 2013), stability in economic variables tends to promote a job-enabling environment with optimal traits of human and social relations (Mpofu, 2015). Further debate on the causality between South Africa's economic growth and employment has stirred much concern across the academic environment (Biyase \& Bonga-Bonga, 2015).

In assessing the impact of movements in the exchange rate, there is limited empirical analysis of this factor conducted in South Africa, while the existing evidence provides conflicting results as to the exact interactions between the appreciation and 
depreciation of the currency and the country's employment or job creation. Ngandu (2008) asserts that an appreciation of the exchange rate promotes employment growth, while results by Bhorat et al. (2014) dispute this notion as their results found a depreciation to be in favour of employment creation. The conflicting results from empirical studies among different developing countries calls further research on this topic.

Despite low levels of economic growth experienced during the period 20082016 (Lipton, 2013), South Africa has enjoyed relatively high employment rates, particularly from the years 1994 to pre-financial crises, if compared to other subSaharan countries (Laubscher, 2013). However, the country's attempts to create jobs have not resulted in a significant decrease in unemployment (Hendriks, 2016). Furthermore, the currency is consistently under pressure and has been depreciating during the years, resulting in increased labour costs and production costs. It remains unclear as to whether the aforementioned factors significantly promote a social and economic platform suitable for the establishment of a job-enabling environment within South Africa. It is evidently important to analyse how South Africa's employment rate responds to changes in these factors. This study therefore examines short- and long-run interactions between the mentioned economic variables namely, exchange rate, economic growth, and job creation in South Africa.

\section{Literature Review}

Klein et al., (2002) and Fujita \& Nakajima, (2016) encapsulate the trends and movements in the labour market using the flow approach to the labour market. This approach classifies the labour market's net employment within two main categories, consisting of worker flows and job flows. Worker flows suggest that workers are either employed or unemployed, or moving between jobs under conditions of supply-side events in the labour market's labour-force entry (Burgess et al., 2000); whereas the movement or mobility of workers in switching or searching for jobs is driven by incentives of better wages or working conditions, or changes in any attributes pertaining to career development (Davis et al., 2005). Developments in job creation or job losses, however, are captured under job flows, reflecting firms' demand for labour in the labour market based on demand-side events (Klein et al., 2002). For the purpose of this study, the focus is placed on establishments of job flows in assessing trends and movements within job creation. Bonner et al. (2011) and Fujita and Nakajima (2016) define job creation as the aggregate increase in employment across all establishments following their start-up period to the point of expansion. Similarly, Klette and Mathiassen (1996) assert that job creation is the change in the level of employment of all establishments that intensifies employment.

While employment-related indicators play a prominent role in understanding the overall macro-economic performance (Kapsos, 2006), they also indicate the dimension of challenges faced by job flows (Martins \& Takeuchi, 2013). Consequently, uncertainties or unforeseen shocks to job flows may affect job creation dynamics (Riegler, 2014). As a result, labour markets in global economies, particularly developing countries, are faced with perpetual challenges in making provision for sustainable and decent jobs (Meyer, 2014). Davis et al. (2006) emphasises the use of high-quality job-related indicators in obtaining precise flows in the labour market to avoid "spurious 
entry and exit" results: implying that broken links may over-exaggerate movements in job creation. Growth is a crucial determinant of job flows and employment (Tattara \& Valentini, 2004), as it promotes labour productivity resulting in gains in employment growth (Kapsos, 2005).

Economic theory asserts that fluctuations in the exchange rate, resulting in foreign goods and domestic price changes, may affect the reallocation of resources within economic sectors (Alexandre et al., 2011). Thus job flows tend to be highly sensitive to changes in relative prices and exchange rate fluctuations, as trade liberalisation (openness) is accompanied by extreme demand volatility and shocks to firms (Haltiwanger et al., 2004). A depreciation in the exchange rate increases or promotes the growth of local jobs in the manufacturing and non-manufacturing sectors (tradable sectors) (Yokoyama et al., 2015). Therefore, maintaining exchange rate stability implies controlling a country's level of unemployment (Chimnani et al., 2012). Literature (Bhorat et al., 2014; Huang \& Tang, 2015) suggests that it is plausible for an appreciation in the exchange rate to be detrimental to employment growth in tradable sectors such as the manufacturing sector. Domestic exports become more expensive relative to foreign exports in the face of an appreciation of the domestic currency. As such, demand for tradable sectors' exports decreases, whereas this effect is stronger for export reliant industries. Inversely, currency appreciation is beneficial to nontradable sectors as it are expected to increase output and employment for net importers of inputs. In essence, a depreciation is beneficial to tradable sectors, whist an appreciation proves detrimental. Impacts of an appreciation of the domestic currency result in a positive employment effect for non-tradable sectors, whist a depreciation negatively affects non-tradable sectors. This study consequently compares the changes in aggregate employment growth to changes in the real exchange rate and GDP growth.

\subsection{Job creation and economic growth}

Callen (2008) and Tjukanov (2011) define gross domestic product (GDP) as a monetary measurement of a country's value of all final goods and services produced within a specific period. Okun's Law points out that increased output corresponds with higher employment, exhibiting a positive correlation between GDP and employment (Guisinger et al., 2015). Increased GDP inhibits the growth of the unemployment rate (Okun, 1962). The broad consensus on economic growth is that it remains a job driver and an essential macro-economic facet for promoting a job-enabling environment (Altman, 2003; Chili, 2000). It thus serves as a general prerequisite in securing a job-enabling social and economic platform. Nevertheless, Schmid (2008) maintains that the measure of job creation depends on the direction of economic growth resulting from either extensive or intensive growth. Under the extensive growth strategy, increased growth is accompanied by an expansion of inputs, encompassing an increase in the labour force and capital accumulation. However, extensive growth is liable to diminishing marginal returns in the long-run (Allen, 1986). Intensive growth is thereby accompanied by increased growth in aggregate output per increase in each input (Irmen, 2005).

Despite South Africa's periods of increased economic growth since the year 1994, the country's high unemployment rate serves as an indication of the "jobless growth" dilemma (Leshoro, 2013). Amidst increased international economic integration 
and globalisation, Altman (2003) responds to disparities in the conventional "jobenabling growth" dynamics by highlighting that South Africa's employment and investment multiplier effects are limited by the country's supply constraints within its production structure, as it is mainly capital-intensive. For this reason, the country's growth is not labour absorbing as it relies on intensive rather than extensive growth within the mentioned production structure (Altman, 2003). Countries with highly protective labour markets display a low responsiveness of employment to changes in economic growth. As such, these countries often exhibit higher levels of unemployment rates as a result of strict labour laws (Sögner \& Stiassny, 2000). Therefore, it follows that the reaction of employment to GDP in these countries is weak. The question remains as to whether South Africa experiences job-enabling growth or growth accompanied by joblessness. Keynes (1937) emphasises that equilibrium is present where full-employment exists, particularly, where changes in investment and savings translate into changes in aggregate demand, thereby affecting the level of GDP. Hence, alterations in GDP due to fluctuations in aggregate demand regulate employment levels (Leshoro, 2013). Such an impact is also dependent on each country's prevalent type of economic growth, whether extensive or intensive, as it differs accordingly in each country (Herman, 2011).

Studies conducted by Funlayo (2013), and Sodipe and Ogunrinola (2011), assessing the relationship between employment and economic growth in Nigeria by means of the Johansen vector-error correction model, found a positive relationship between employment and economic growth. Further findings by Herman (2011) on the assessment of employment effects of economic growth on countries in the European Union (EU) suggest a significant, but yet low responsiveness of employment towards economic growth dynamics in each of the EU countries. The author further highlights that the low employment responsiveness resonates from the different employment intensity of an "economic growth process" at the EU level, particularly those in Central and Eastern EU. The type of economic growth, either extensive or intensive growth, may explain the rhythm of employment intensity. Employment effects on economic growth may additionally be determined labour market characteristics and labour flexibility in the EU.

Furthermore, based on the Toda-Yamamoto technique of causality during the periods 2000 to 2012, Leshoro (2013) established that economic growth Granger causes employment in South Africa, while causality from employment to economic growth was non-existent. Further studies by Biyase and Bonga-Bonga (2015) using a structural vector autoregressive model during the years 1970 to 2008 , assessing the responsiveness of South Africa's employment rate to economic growth, suggested a weak or non-responsive reaction of employment to GDP growth, justifying the existence of jobless growth in the country. On the other hand, co-integration results by Vermeulen (2015) revealed a long-run co-integrating relationship between the variables whilst Granger causality test results suggested that employment is driven by economic growth. Similarly, Habanabakize and Muzindutsi (2015) found that the economic growth, measured by aggregate expenditure, has significant positive long-run effect on the job creation in South Africa.

\subsection{Job creation and exchange rate movements}

The exchange rate serves as an important price factor in the economy (Klein \& Shambaugh, 2012). Gourinchas (1999) defines this as a measurement of the price of a country's domestic currency relative to a foreign basket of goods or prices. While 
developing countries are mostly subjected to exchange rate volatility, Ozturk (2006) defines such volatility as the risk resulting from unanticipated shocks in the exchange rate. Van der Merwe and Mollentze (2010) categorise measurements of exchange rate under nominal and real exchange rates. Fluctuations in a nation's currency or exchange rate exert changes in domestic production costs (Ngandu, 2008). Nucci and Pozzolo (2010) state that the exchange rate affects the labour market based on channels of appreciation and depreciation of currencies. Estimates by Ribeiro et al. (2004) suggest that the effect of exchange rate on gross job flows is uneven; as such, an appreciation of the currency exchange rate will lead to a decrease in total job growth.

Employment or job flows are influenced by exchange rate movements based on three possible channels (Campa \& Goldberg, 2001). These firstly include increased import penetration via demand shocks caused by increased competitiveness of local output markets. Secondly, export orientation, via increased sectoral focused export, resulting in competitiveness shocks. Lastly, the use of imported inputs also does, where changes in input costs result in variations in costs and prices (depreciation in the domestic currency raises the costs of factors of production). The extent of openness of a country's industry is another determining factor in terms of which any changes in the real exchange rate affect an industry's level of employment or job creation (Klein et al, 2003). In addition, the magnitude of the response of the labour market to exchange rate movements relies on market and regulatory forces (Burgess \& Knetter, 1998). Belke and Kaas (2004) argue that extreme volatility in a country's exchange rate is likely to discourage firms from employing more workers. As employment and investment decisions are characterised by high levels of irreversibility in the face of rigid corporate structures, the cost of reversing the decision to hire a worker is high (Erdal, 2001). Literature also suggests that changes in the real exchange rate and trade liberalisation/international openness (tariffs and non-tariff obstacles) have a direct effect on the flow or rate of job creation, including the pace at which jobs are destroyed (Klein et al., 2002).

Further analysis by Kim (2005) of Korea's industries in terms of the exchange rate and its effect on employment revealed a positive response of employment to exchange rate shocks, while industries with low or moderate exposure to foreign trade maintained a negative correlation. Subsequently, a study by Alexandre et al. (2010) suggested that sectors with low levels of technological development are more open to foreign trade and thus more sensitive to exchange rate movements; as a result, such sectors experience a sizable amount of job destruction in the face of changes in the exchange rate. Studies by Chen and Dao (2011) showed a contraction of China's tradable and non-tradable sectors as a result of an appreciation of the country's exchange rate. Similarly, a significant effect of the exchange rate and employment levels were observed in Ghana's manufacturing sector, such that a depreciation in Ghana's currency inhibited the level of job creation (Mensah et al., 2013). Moreover, Alexandre et al. (2011) noted that employment in technology driven sectors is relatively resistant to movements in the real exchange rates.

Ngandu (2009) analysed the effect of movements in the exchange rate on employment in South Africa using the computable general equilibrium model (an economy-wide approach). The study revealed that an appreciation in the ZAR tends to shift employment from tradable sectors such as manufacturing to non-tradable sectors. Where an appreciation in the exchange rate increased demand and spending in non- 
tradable sectors, it however decreased foreign demand in tradable sectors resulting from increased export prices. Nonetheless, the study asserts that the country still experiences increased aggregate employment as non-tradable sectors absorb lost jobs in tradable sectors. Mpofu (2013) assessed the impact of real exchange rate movements on South Africa's manufacturing sector using Autoregressive Distributed Lag (ARDL) during the period 1995 to 2010 . The results revealed that a depreciation in the exchange rate results in employment growth in the manufacturing sector. Whereas results by Bhorat et al. (2014) based on the years from 1975 to 2009 revealed a strong negative impact where an appreciation of the local currency (ZAR) resulted in decreased employment in the tradable sector, while having no effect on non-tradable sectors.

\section{Methodology}

\subsection{Data description}

The study follows a quantitative approach based on a dataset of 80 quarterly observations of total non-agricultural employment, GDP in ZAR value at constant prices and the real exchange rate movements of the ZAR versus the US dollar (USD). Adjustments for inflation of both GDP and the exchange rate were made to obtain real values. The data was derived from the South African Reserve Bank (SARB) starting from the first quarter of 1995 to the fourth quarter of 2015. The starting sample period is affected by the change in South Africa's economic and political system and the exclusion of the effects of the apartheid regime's economic embargo.

\subsection{Model specification}

In determining the interactions of the selected variables with employment, the general function of the study is expressed as follows:

$$
\text { LEMP }=f(\text { LREXCH, LGDP) }
$$

Where: LEMP is the natural logarithm of the level of employment, $L R E X C H$ is the natural logarithm of the real exchange rate and LGDP is the natural logarithm of the real gross domestic product. All variables were converted to their natural logarithms for the adjustment of any likelihood of scale effect and to estimate growth or elasticities. In the function of employment, Equation (1), there is a likelihood of the dependent variable being affected by endogenous and exogenous lags resulting from its past associations and those of independent variables. The Vector Autoregressive model (VAR) is thus used in regressing the multivariate relationships into a finite-order structure as suggested by Sims (1980). The VAR model forms a starting point for further analysis such as co-integration, impulse response and variance decomposition analyses and causality tests (Muzindutsi \& Maepa, 2014; Niyimbanira, 2015). The VAR model from the aforementioned function in Equation (1) is expressed as follows:

$$
\begin{aligned}
& L E M P_{t}=\alpha_{1}+\sum_{j=1}^{k} \beta_{1 j} L E M P_{t-\mathrm{j}}+\sum_{\mathrm{j}=1}^{\mathrm{k}} \lambda_{1} L R E X C H_{\mathrm{t}-\mathrm{j}}+\sum_{\mathrm{j}=1}^{\mathrm{k}} \gamma_{1 j} L G D P_{t-\mathrm{j}}+u_{1 t} \\
& L R E X C H_{t}=\alpha_{2}+\sum_{j=1}^{k} \beta_{2 j} L E M P_{t-\mathrm{j}}+\sum_{j=1}^{k} \lambda_{2} L R E X C H_{t-\mathrm{j}}+\sum_{j=1}^{k} \gamma_{2 j} L G D P_{t-\mathrm{j}}+u_{2 t} \\
& L G D P_{t}=\alpha_{3}+\sum_{j=1}^{k} \beta_{3 j} L E M P_{t-\mathrm{j}}+\sum_{j=1}^{k} \lambda_{3} L R E X C H_{t-\mathrm{j}}+\sum_{j=1}^{k} \gamma_{3 j} L G D P_{t-\mathrm{j}}+u_{3 t}
\end{aligned}
$$


Where: $\alpha_{n}$ denotes the constant, $\beta_{n}, \lambda_{n}$ and $\gamma_{n}$ denotes the coefficients; $\mathbf{k}$ is the proxy for the number of lags while the stochastic error or shocks in the VAR model are denoted by $u_{1 t}, u_{2 t}$ and $u_{3 t}$. Prior to conducting the analysis, the Augmented Dickey-Fuller (ADF) test was used to test the variables for stationarity or unit root. The use of non-stationary data may result in "spurious" results implying that results may be misleading (Mushtaq, 2011). If the observed variables are found to be stationary, then the VAR model in Equations 2 to 4 is estimated. However, if all variables are found to be non-stationary then a co-integration test is estimated to determine whether a linear combination of such non-stationary variables is stationary. This is known as the co-integration test for a long-run relationship (Nielsen, 2005).

Johansen's multivariate co-integration method was used in testing the longrun relationship amongst the variables. The existence of co-integrating relationships between the variables further implies undertaking the Vector Error Correction Model (VECM) (Kakes, 2000). Alternatively, the study may proceed with the VAR model of the first differenced variables in case there are no co-integrating relationships. The VECM equations based on our VAR model are as follows:

$$
\begin{aligned}
& \triangle L E M P_{t}=\alpha_{1}+\sum_{j=1}^{k} \beta_{1 j} \Delta L E M P_{t-j}+\sum_{j=1}^{k} \lambda_{1} \Delta L R E X C H_{t-\mathrm{j}}+\sum_{j=1}^{k} \gamma_{1 j} \Delta L G D P_{t-j}+\varphi_{1} u_{1 t-1}+e_{1} \\
& \Delta L R E X C H_{t}=\alpha_{2}+\sum_{j=1}^{k} \beta_{2 j} \Delta L E M P_{t-j}+\sum_{j=1}^{k} \lambda_{2 j} \Delta L R E X C H_{t-\mathrm{j}}+\sum_{j=1}^{k} \gamma_{2} \Delta L G D P_{t-j}+\varphi_{2} u_{2 t-1}+e_{2} \\
& \Delta L G D P_{t}=\alpha_{3}+\sum_{j=1}^{k} \beta_{3 j} \Delta L E M P_{t-j}+\sum_{j=1}^{k} \lambda_{3 j} \Delta L R E X C H_{t-\mathrm{j}}+\sum_{j=1}^{k} \gamma_{3} \Delta L G D P_{t-j}+\varphi_{3} u_{3 t-1}+e_{3}
\end{aligned}
$$

Where: $\Delta$ denotes the first difference operator. Error correction terms are further denoted by $u_{1 t-1} \ldots u_{3 t-1}$. Adjustments for short-run dynamics towards the long-run equilibrium are captured by error correction coefficients denoted by $\varphi_{1} \ldots \varphi_{3}$; while short-run variations of the model are captured by the coefficients $\beta_{n}, \lambda_{n}$ and $\gamma_{n}$. Preceding the interpretation of the VCM output, diagnostic tests are conducted to ensure that the model meets stochastic properties. Further analysis including variance decomposition and impulse response was conducted to assess the proportion of movements in the dependent variable caused by endogenous and exogenous shocks and to assess the responsiveness of the dependent variable to shocks in the error term, respectively (Brooks, 2014).

\section{Empirical Results}

\subsection{Correlation analysis and unit root tests}

Table 1 indicates the relationship between the variables in the correlation analysis. The analysis suggests a strong positive relationship between the log of employment and the log of the real exchange rate, significant at the 0.01 significance level. Log of employment and log of GDP suggest a positive moderate relationship between the series, which is significant at 0.01 significance level. 
Table 1: Pairwise Correlations

\begin{tabular}{crrr}
\hline & LEMP & LEXCH & LGDP \\
\hline LEMP & 1.000000 & 0.540372 & 0.943460 \\
& --- & {$[0.0000]$} & {$[0.0000]$} \\
\hline
\end{tabular}

Note: P-values in [].

Table 2 reports unit root test results of the Augmented Dicky-Fuller test. At level, all variables are non-stationary as the $p$-values are greater than 0.05 , implying that the null hypothesis is rejected at 0.05 significance level. This means that the series exhibits a unit root, with and without trend. At first differences, all variables are stationary as the p-values are less than 0.01 . The null hypothesis is therefore rejected at 0.01 significance level. Therefore, all variables reached the same order of integration at I(1) or first difference. The proceeding step is a test for co-integrating vectors or long run relationship using the Johansen co-integration approach.

Table 2: Augmented Dickey-Fuller Unity Root Test

\begin{tabular}{lccccc}
\hline \multirow{2}{*}{ Variables } & \multicolumn{2}{c}{ Level I(0) } & \multicolumn{2}{c}{ First Difference I(1) } & \multirow{2}{*}{ Result } \\
\cline { 2 - 5 } & t-stat & P-value & t-stat & P-value & \\
\hline LEMP & -2.208194 & 0.4786 & -9.014124 & $0.0000^{\star *}$ & I(1) \\
LEXCH & -1.719281 & 0.7340 & -7.935363 & $0.0000^{* *}$ & $\mathrm{I}(1)$ \\
LGDP & -1.179592 & 0.9078 & -4.526323 & $0.0004^{* *}$ & $\mathrm{I}(1)$ \\
\hline
\end{tabular}

Note: ** denotes stationary series with unit root at $1 \%$ level of significance

\subsection{Lag-length selection criteria}

Prior to conducting the Johansen co-integration test, a lag order selection process was used to select and determine the number of lags to be used in this test, including the vector error correction model (VECM). The optimal lag selection was based on five selection criteria, namely; LR, FPE, AIC, SC and HQ, where all criteria reached the same conclusion of 2 lags. Therefore, 2 lags were used with intercept and no trend in the Johansen co-integration test and VECM.

\subsection{Co-integration test results}

Table 3 reports results for the Trace test and Max-Eigenvalue statistics in the Johansen co-integration test with intercept and no trend. The trace statistic shows one co-integrating equation $(r \leq 1)$ at 0.05 level of significance. However, the null hypothesis of no co-integrating equation $(r=0)$ is accepted for the MaxEigenvalue as it failed to support Trace test results. The results obtained in the MaxEigenvalue, of no co-integration compared to the Trace statistic, remain in favour of the study. The Trace test statistic has proven to be superior and outperforms the MaxEigenvalue when working with large data samples (Saikkonen \& Luetkepohl, 2000). Thus, the null hypothesis of no co-integrating equation is therefore rejected. This suggests that variables are co-integrated or that a long-run relationship exists within the series. 
Table 3: Johansen co-integration test results

\begin{tabular}{lcccccc}
\hline $\begin{array}{c}\text { H0: No. of } \\
\text { CE(s) }\end{array}$ & \multicolumn{4}{c}{ Trace Test } & \multicolumn{3}{c}{ Maximum Eigenvalue } \\
\cline { 2 - 7 } & $\begin{array}{c}\text { Trace } \\
\text { Statistic }\end{array}$ & $\begin{array}{c}\text { T-critical } \\
\text { value }\end{array}$ & $\begin{array}{c}\text { P- } \\
\text { values* }\end{array}$ & $\begin{array}{c}\text { Max-Eigen } \\
\text { Statistic }\end{array}$ & $\begin{array}{c}\text { T-critical } \\
\text { value }\end{array}$ & $\begin{array}{c}\text { P- } \\
\text { values* }\end{array}$ \\
\hline None* $^{*}$ & 37.17346 & 35.19275 & $0.0302^{*}$ & 18.87637 & 22.29962 & 0.1406 \\
At most 1 $^{\text {At most 2 }}$ & 18.29708 & 20.26184 & 0.0911 & 13.05709 & 15.89210 & 0.1326 \\
\hline
\end{tabular}

${ }^{*}$ denotes rejection of $\mathrm{H}_{0}$ at 0.5 significance level

\subsection{Long-run relationship}

The existence of a co-integrating relationship between LEMP, LREXCH and LGDP suggests that the selected variables explain the long-run equilibrium in LEMP. The long-run relationship is expressed in Equation (8) as follows:

$$
\text { LEMP = -18.0107-0.5059(LREXCH) + } 0.8710 \text { (LGDP) }
$$

In the long-run (Equation 8), there is a negative relationship between the real exchange rate and employment: meaning that a depreciation in the ZAR leads to a decrease in employment. As such, a one percent depreciation in the ZAR against the USD dollar induces a 0.51 percent decrease in employment. Nevertheless, Equation 8 indicates a positive relationship between GDP and employment, suggesting that an increase in GDP induces an increase in employment. Therefore, a one percent increase in GDP induces an increase in employment by 0.87 percent.

\subsection{Short-run relationships}

All variables being co-integrated, VECM can be estimated to explain shortrun adjustments towards the long-run equilibrium (Magee, 2013; Noumbissie \& Mongale, 2014). Therefore, it follows that a negative adjustment coefficient (error correction term) and a significant t-value are conditions in explaining short-run adjustments towards the long-run equilibrium (Mukhtar \& Rasheed, 2010). The VECM output (Table 4) indicates that CointEq1 constitutes two significant equations which explain the existence of shortrun adjustment towards the long-run equilibrium in LREXCH and LGDP. These results provide a robust set of items of evidence of error correction in the first co-integrating equation. LREXCH and LGDP have negative coefficients; -0.207265 and -0.016806 and t-values of -2.58155 and -3.08642 , respectively. Both variables are significant at 0.05 significance level. The log of the real exchange rate and the log of GDP exhibit evidence of error correction in the first co-integrating equation. This suggests that equilibrium is restored in the real exchange rate and GDP equations. Therefore, about 20.7 percent of the disequilibrium in LREXCH is corrected/ adjusted in each quarter and it takes approximately 5 quarters to reach full equilibrium; whilst 1.6 percent of the disequilibrium in LGDP is corrected in each quarter and takes approximately 60 quarters to reach full equilibrium. 
Table 4: Vector Error Correction Model results

\begin{tabular}{cccc}
\hline \hline Error Correction: & $\mathrm{D}(\mathrm{LEMP})$ & $\mathrm{D}(\mathrm{LREXCH})$ & $\mathrm{D}(\mathrm{LGDP})$ \\
\hline \hline CointEq1 & 0.039189 & -0.207265 & -0.016806 \\
& {$[0.87868]$} & $[-2.58155]]^{* *}$ & {$[-3.08642]$} \\
$\mathrm{D}($ LEMP(-1)) & -0.084972 & -0.296781 & 0.014020 \\
& {$[-0.67049]$} & {$[-1.30090]$} & {$[0.90611]$} \\
$\mathrm{D}($ LEMP $(-2))$ & -0.109822 & -0.078032 & 0.026680 \\
& {$[-0.91360]$} & {$[-0.36061]$} & {$[1.81787]{ }^{*}$} \\
D(LREXCH(-1)) & -0.109134 & 0.120523 & -0.006007 \\
& {$[-1.79560]$} & {$[1.10156]$} & {$[-0.80956]$} \\
D(LREXCH(-2)) & -0.001360 & -0.148519 & -0.002857 \\
& {$[-0.02214]$} & {$[-1.34266]$} & {$[-0.38084]$} \\
D(LGDP(-1)) & 1.349974 & -1.916694 & 0.523291 \\
& {$[1.40329]$} & {$[-1.10679]$} & {$[4.45530]$} \\
& 0.860603 & 0.840217 & 0.051673 \\
D(LGDP $(-2))$ & {$[0.87495]$} & {$[0.47453]$} & {$[0.43028]$} \\
\hline \hline
\end{tabular}

* denotes significance at $10 \%$. ${ }^{* *}$ denotes significance at $5 \%$

Results of the employment equation (Table 5) indicate that the t-value of LREXCH(-1) is above 1.645 critical t-value, which is statistically significant at the 10 percent level of significance. This implies that there is a significant negative shortrun relationship between the log of employment and the real exchange rate; meaning that past changes in the real exchange rate have a significant negative effect on the current change in employment. A depreciation of the ZAR in the previous quarter induces a decrease in current employment growth. Moreover, the second lag of the log of employment and the first lag of the log of GDP in the GDP equation are positive and statistically significant at the 0.05 significance level. This implies that past changes in employment affect current changes in GDP, while previous shocks in GDP result in its current changes. To confirm these results, Granger causality, variance decomposition and impulse response tests were conducted.

\subsection{Granger-causality test}

Similar to ECT results, further analysis, recorded in Table 5, indicates a oneway causal relationship from LGDP to LEMP and LEXCH to LEMP, meaning that short-run changes in economic growth and the real exchange rate cause changes in employment levels: exhibiting a one-way causality from GDP to employment and real exchange rate to employment. These results are reinforced by the variance decomposition results in Table 6. 
Table 5: Pairwise Granger Causality results

\begin{tabular}{|l|l|l|}
\hline Null Hypothesis & F-statistic & P-value \\
\hline LEXCH does not Granger Cause LEMP & 3.93172 & $\mathbf{0 . 0 2 3 7}{ }^{*}$ \\
\hline LEMP does not Granger Cause LEXCH & 1.81362 & 0.1700 \\
\hline LGDP does not Granger Cause LEMP & 5.69116 & $\mathbf{0 . 0 0 5 0}$ \\
\hline LEMP does not Granger Cause LGDP & 0.16239 & 0.8504 \\
\hline LGDP does not Granger Cause LEXCH & 0.85738 & 0.4283 \\
\hline LEXCH does not Granger Cause LGDP & 1.23503 & 0.2965 \\
\hline
\end{tabular}

* reject null hypothesis of no Granger causality at 0.05 significant level

\subsection{Variance Decomposition}

Results of Granger causality are supported by results in the variance decomposition (Table 6). Employment is affected by its own shocks, and employment shocks are also caused by shocks in economic growth and the real exchange rate. The effect of these shocks increases successively from the $2^{\text {nd }}$ to the $10^{\text {th }}$ quarter or period. In the second quarter, 97.1 percent of shocks in employment rate is due to its own shocks, while the remaining 2.9 percent is caused by shocks in the real exchange rate and real GDP. A point to note is that exchange contributes more $(1.64 \%)$ to these shocks than the GDP $(1.26 \%)$. Confirming the short-run effect of real exchange rate on employment rate, established by the VECM results. In the fourth quarter, 89.2 percent of shocks in the employment rate are caused by its own shocks, whereas shocks in economic growth and the real exchange rate explain about 11.2 percent of variations in employment during the fourth period. As of the 10th period, 19.6 percent and 5.2 percent of variations in employment are explained by economic growth (LGDP) and the real exchange rate, respectively, while 75.2 percent of shocks in employment are explained by its own variations. Granger causality, variance decomposition and impulse response results confirm results provided in the VAR analysis.

Table 6: Variance decomposition results of LEMP

\begin{tabular}{ccccc}
\hline Period & S.E. & LEMP & LREXCH & LGDP \\
\hline 1 & 0.040293 & 100.0000 & 0.000000 & 0.000000 \\
2 & 0.056061 & 97.10599 & 1.635231 & 1.258775 \\
3 & 0.068860 & 92.61041 & 2.390748 & 4.998842 \\
4 & 0.081768 & 89.19624 & 2.609287 & 8.194477 \\
5 & 0.094260 & 86.22520 & 2.979641 & 10.79516 \\
6 & 0.106063 & 83.44778 & 3.436910 & 13.11531 \\
7 & 0.117264 & 81.00502 & 3.873071 & 15.12191 \\
8 & 0.127893 & 78.86670 & 4.302673 & 16.83063 \\
9 & 0.137972 & 76.95420 & 4.740392 & 18.30541 \\
10 & 0.147542 & 75.22577 & 5.183164 & 19.59107 \\
\hline
\end{tabular}




\subsection{Impulse Responses}

In assessing the responsiveness of variables to shocks resulting from exogenous and endogenous variations, these reactions are measured through impulse responses as depicted in Figure 1. Considering the responsiveness of employment to shocks in the real exchange rate, such shocks tend to result in a significant negative effect on South Africa's employment. Such effects do not tend to decrease across the 15th quarter period as they seamlessly induce a decrease in employment moving forward. This confirms the VECM results of negative relationship between the real exchange and the empolyment. On the other hand, shocks in GDP cause a positive significant impact on employment. As such, employment tends to increase from the mid first-second quarter across the few quarters. Such an effect becomes positively consistent up to the $7^{\text {th }}$ quarter. However, the positive impact is seemingly maintained as at it approaches the $8^{\text {th }}$ to $15^{\text {th }}$ quarter. Once, again this confirms the long-run results of a positve long-run relationship between real GDP and the real echange.

\section{Fig. 1: Impulse response test results}

Response to Cholesky One S.D. Innovations

Response of LEMP to LEMP

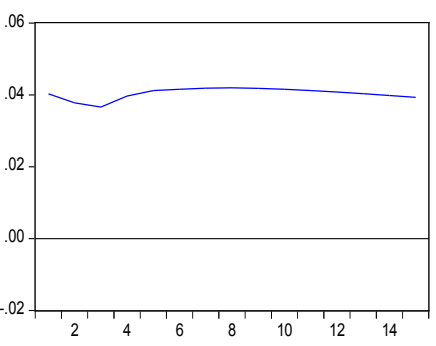

Response to Cholesky One S.D. Innovations

Response of LEMP to LEXCH

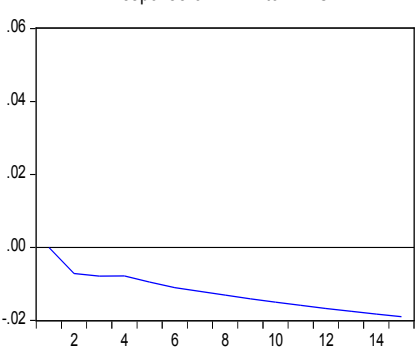

Response to Cholesky One S.D. Innovations

Response of LEMP to LGDP

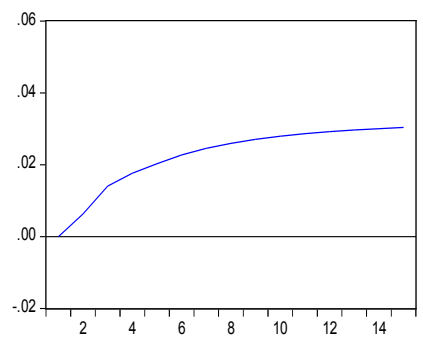

\subsection{Diagnostic testing}

The underlying model passed diagnostic tests of no heteroscedasticity and no serial correlation, with results shown in Table 7. Nevertheless, the model failed the Jacque-Bera normality test at 0.05 level of significance. However, it is natural to reject the null hypothesis of normality testing in large data samples as they do not possess an " $\alpha$-stable" distribution (Frain, 2007). This implies that some regressions are not constant over time (Ruxanda \& Botezatu, 2008) and that normality testing is sensitive to increased sample sizes (Kundu et al., 2011). Thus the null hypothesis in the test for normality may be rejected "more often than it should" (Chen \& Kuan, 2003). Stability testing is mandatory in the case of a failed Jarque-Bera test (Zanini et al., 2000). AR root test estimates can further be estimated (Razali \& Wah, 2011; Hain, 2010). Results of the AR root test confirm the stability of the model as all AR roots lie within the unit circle, making it appropriate to proceed with causality, impulse and variance decomposition testing. The results of the stability test also confirms that the relationship between the employment, the real exchange rate and the real GDP was consistent throughout the sample period. Thus, changes in economic stability, such as the 2008 financial crisis, did not affect the relationship between these variables. 
Table 7: Diagnostic tests results

\begin{tabular}{llll}
\hline Test & HO & Probability & Decision \\
$\begin{array}{l}\text { LM } \\
\text { Test }\end{array}$ & $\begin{array}{l}\text { No serial } \\
\text { correlation }\end{array}$ & 0.0937 & $\begin{array}{l}\text { With a P-value above 5\%, do not reject } \\
\text { the HO. Therefore, there is no serial } \\
\text { correlation in the model. }\end{array}$ \\
$\begin{array}{l}\text { White } \\
\text { (CT) }\end{array}$ & $\begin{array}{l}\text { No } \\
\text { heteroscedasticity }\end{array}$ & 0.8800 & $\begin{array}{l}\text { With a P-value above 5\%, do not reject } \\
\text { the H0. Therefore, there is no } \\
\text { heteroscedasticity in the model. }\end{array}$ \\
$\begin{array}{l}\text { Jarque- } \\
\text { Bera } \\
\text { nesiduals are } \\
\text { normally } \\
\text { distributed }\end{array}$ & 0.000 & $\begin{array}{l}\text { With a P-value less than 5\%, reject H0. } \\
\text { Therefore, the results show that the data } \\
\text { is not normally distributed. }\end{array}$ \\
\hline
\end{tabular}

Inverse Roots of AR Characteristic Polynomial shows that the VEM is stable

\section{Discussion of results}

The positive and significant long and short-run relationships between employment and GDP, together with causality results, are supported by Leshoro (2013). However, contrary to the results recorded by Biyase and Bonga-Bonga (2015) during the years 1970 to 2008, of a weak and non-responsive reaction of employment to GDP growth suggesting jobless growth, the results of this study show that economic growth does have a positive impact on job creation, but the impact is low. In addition, the Granger causality results indicated that economic growth does cause employment growth. This result is similar to the results established by Leshoro (2013) and Hanabakize and Muzindutsi (2105) for South Africa and Funlayo (2013) for Nigeria.

Further results in the variance decompositions results suggest that the growth in employment corresponds with increased GDP growth. The descriptive analysis of this study shows that employment growth has been significantly increasing along with economic growth since 1994. However, findings within the impulse response test of the current study demonstrate that the growth in employment has not been significant from the $8^{\text {th }}$ quarter to the $15^{\text {th }}$ quarter although it has remained constant. This can be explained by the country's low economic growth post the 2008-2009 global financial crisis, which has recorded moments of negative economic growth at certain times during the period. However, variance decomposition in this study suggests that shocks in GDP explain $24 \%$ of shocks in the country's employment during the $15^{\text {th }}$ quarter. Seeing that the results revealed that GDP has a significant impact on employment growth, as suggested by Okun's law and assumptions by Keynes (1937), it is therefore best to find effective ways of boosting the growth of the country's economy in order to stimulate job creation.

Furthermore, contrary to the results by Ngandu (2009), the study established a significant negative short-run and long-run relationship between employment and the real exchange rate. These results confirm results by Mpofu (2013) and Bhorat et al. (2014) of a significant negative relationship between the two variables where an depreciation in the rand decreases employment growth, while an appreciation in the 
rand promotes job creation. Significant employment effects of changes in the real exchange rate correspond with results by Alexandre (2011) in low technology sectors, whereas these findings where however offset by a non-compliance of employment towards exchange rate movements in high technology sectors. Simply indicating the negative effects of capital intensive other than employment intensive production on employment growth. Therefore, the country's high unemployment rate of 26.6 percent could be explained by the country's volatile and unstable currency and low economic growth as supported by variance decomposition and impulse response results.

\section{Conclusion and recommendations}

The creation of jobs is at the centre of economic growth and development. Globally, economies are under pressure with the phenomenon of jobless growth becoming a growing problem due to technology and innovation. The creation of sustainable jobs assists in maintaining economic and social stability. Persistent structural unemployment has major negative long run impacts on developing countries specifically on individuals and firms. It leads to decline in aggregate demand by consumers, which affects business development and success negatively. Considering that job creation is beneficial to both firms and individuals, the study focused on creating a job-enabling platform that sustains South Africa's businesses and its people. As such, the study examined the factors resulting in job dynamics by assessing the short and long run relationships between South Africa's aggregate employment growth and the country's real exchange rate and GDP growth. The extent and degree of employment responsiveness to the aforementioned factors were further investigated.

Despite having a significant but yet low employment elasticity to economic growth for both variables, the results revealed that, in the long-run, employment growth is more responsive to changes in economic growth than those in the real exchange rate. A greater percentage change in employment is explained by GDP growth. However, both factors have a significant impact on the country's employment. Effects of the real exchange rate may be such that the real exchange rate affects the country's employment through its economic growth. The research confirmed that the stability of the local currency is vital for economic growth and employment creation. The exchange rate volatility however has different impacts on job creation in different sectors as well as on imports and exports. Further studies may be conducted investigating the impact and percentage changes in economic growth explained by real exchange rate fluctuations when different sectors are considered.

Results of low employment responsiveness to economic growth correspond with results by Herman (2011) of low employment elasticity to economic growth based on the economic growth process. Both results highlight the importance of sound labour market institutions and labour flexibility in intensifying employment responsiveness to economic growth as well as employment befitting exchange rate movements. Labour flexibility takes on aspects such as the ease of wage negotiations. The creation and sustenance of extensive growth processes remains vital for intensifying employment elasticity to growth for South Africa and other various developing countries. Similarly, these developments may contribute towards intensifying the pace and reallocation process of jobs within economic sectors upon facing fluctuating movements in the exchange rate. 
Since the study investigated the relationship of the changes in aggregate employment levels to exchange rate fluctuations, further studies should be conducted to investigate sectoral changes in employment in terms of changes in such fluctuations in order to determine the sectors that are most sensitive to currency fluctuations and those that maintain the growth in the country's employment. In this regard the findings of current sectoral literature are in conflict. On the other hand, more studies can be conducted to examine the extent of South Africa's sensitivity in creating jobs as a result of its level of openness to trade or trade liberalization. As suggested in the literature, further employment growth may be achieved with fewer labour regulations for increased productivity and growth, considering that South Africa's unemployment rate may be explained by the existence of structural unemployment (Malakwane, 2012). This indicates a mismatch between jobs. Training people with skills suitable for the right jobs may occupy more jobs. Maintaining stability in the country's currency exchange rate to prevent unexpected shocks may prove beneficial for job creation. Moreover, amidst South Africa's trade exposure, promoting skills training and more labour intensive export industries could be beneficial for job creation rather than the existing capital-intensive export industries mentioned by Altman (2003).

The study proposes new findings of a more comparative assessment of employment effects of economic growth and the real exchange rate dynamics. Then again, the results suggest that both variables, "economic growth and the real exchange rate", albeit not significantly impressive, comparatively establish an environment inductive for employment generation. South Africa's highly protective labour laws convey the implied rationale for low employment gains of economic growth and real effective exchange rate as aforementioned by Sögner and Stiassny (2000) in the study. Likewise, other inhibiting include rigid labour market structures as aforementioned. A further relaxation of the country's labour laws may oversee enhanced responsiveness of employment gains to economic growth as well as the intended employment benefits of exchange rate induced job reallocation dynamics. Moreover, our findings reinforce the "jobless growth" agenda revealed by previous studies, further stressing the need to proliferate state policies and actions focused on raising employment effects of economic growth. Future research could include a comparative analysis of labour laws and policy in developing countries.

In conclusion, recommendations to assist policy formulation in ensuring a job-enabling environment in a developing country include; necessitating the need for substantial economic growth to spur employment growth; and making provision of a stable currency with exchange rate required boosting economic growth and employment growth. In addition, labour regulations need to be job creation friendly; the mismatch in skills need to be rectified by means of appropriate skills training; the promotion of small business development and entrepreneurship; labour intensive programmes by the private and public sector should be encouraged. Lastly, export promotion programmes should be implemented. 


\section{References}

*IDC (Industrial Development Corporation) (2016). Economic trends: Key trends in the South African economy. http://www.idc.co.za/images/download-files/ economic-overviews/RI-publication-Keytrends-in-SAeconomy_March2016.pdf. Date of access: 09 November 2016.

*ILO (International Labour Organisation) (2016). World employment social outlook. http://www.ilo.org/wcmsp5/groups/public.pdf. Date of access: 24 March 2016.

* Deloitte. (2016). Rand depreciation a boon for South African outsourcing industry. $\mathrm{H}$ ttps://www2.deloitte.com/content/dam/Deloitte/za/Documents.pdf. Date of access: 14 September 2016.

Abdel-Moneim, M. A. (2015). A political economy of Arab education: Policies and comparative perspectives. New York: Routledge.

Alexandre, F., Bacao, P. M. A., Cerejeira, J. \& Portela, M. (2010). Employment, exchange rates and labour market rigidity. IZA Discussion Paper, 4891(1):132.

Alexandre, F., Bação, P.M.A, Cerejeira, J. \& Portela, M. (2011). Employment and exchange rates: The role of openness and technology. Open Economies Review, 22(5):969-984.

Allen, R.C. (1986). Growth and fluctuations in the BC economy. Vancouver: Canada. Altman, M. (2003). Jobless or job creating growth? Some preliminary thoughts. Employment and Economic Policy Research Program, Human Sciences Research Council. Paper Presented at the TIPS/ DPRU Annual Forum. http://intranet.hsrc.ac.za. Date of access: 02 November 2016.

Belke, A. \& Kaas, L. (2004). Exchange rate movements and employment growth: An OCA assessment of the CEE economies. Empirica, 31(3):247-280.

Bergh, G. \& Zanker, F. (2013). What is the evidence on the impact of employment creation on stability and poverty reduction in fragile states. London: Overseas Development Institute.

Bhorat, H., Tian, N. \& Ellyne, M. (2014). The real exchange rate and sectoral employment in South Africa. DPRU working paper no. 201404. Cape Town: University of Cape Town.

Biyase, M. \& Bonga-Bonga, L. (2015). The relationship between growth and employment in South Africa: structural vector autoregressive analysis. Environmental Economics, 6(2):54-58.

Bonner, K., Anyadike-Danes, M. \& Hart, M. (2011). Job creation and destruction in the UK: 1998- 2010. Birmingham: Aston University.

Brooks, C. (2014). Introductory econometrics for finance. $3^{\text {rd }}$ ed. Cambridge: Cambridge University Press.

Burgess, S. M. \& Knetter, M. M. (1998). An international comparison of employment adjustment to exchange rate fluctuations. Review of International Economics, 6(1):151-163.

Burgess, S., Lane, J. \& Stevens, D. (2000). Job flows, worker flows, and churning. Journal of Labour Economics, 18(3):473-502.

Callen, T. (2008). What Is Gross Domestic Product? http://www.imf.org/external/ pubs.pdf. Date of access: 21 October 2016.

Campa, J. M. \& Goldberg, L. S. (2001). Employment versus wage adjustment and the US dollar. Review of Economics and Statistics, 83(3):477-489. 
Chen, R. \& Dao, M. 2011. The real exchange rate and employment in China. IMF Working Papers, 148(11):1-50.

Chen, Y. T. \& Kuan, C. M. (2003). A generalized Jarque-Bera test of conditional normality. Working paper no. 03-A003. Taipei: Institute of Economics, Academia Sinica.

Chili, N. A. (2000). Economic growth and employment in South Africa: A critical policy analysis. Doctoral Dissertation, formerly: Rand Afrikaans University, now University of Johannesburg.

Chimnani, H., Bhutto, N. A., Butt, F., Shaikh, S. A. \& Devi, W. (2012). Exchange rate and unemployment. http://umt.edu.pk/icobm2012/pdf/2C-84P.pdf. Date of access: 10 October 2016.

Davis, S. J., Faberman, R. J. \& Haltiwanger, J. (2006). The flow approach to labour markets: New data sources and micro-macro links. The Journal of Economic Perspectives, 20(3):3-26.

Davis, S. J., Haltiwanger, J. \& Faberman, R. J. (2005). The flow approach to labour markets: New data sources, Micro-Macro Links and the Recent Downturn. Discussion paper no. 1639. College Park: University of Maryland.

Erdal, B. 2001. Investment decisions under real exchange rate uncertainty. Central Bank Review, 1(1):25-48.

Frain, J. C. 2007. Small sample power of tests of normality when the alternative is an $\alpha$ - stable distribution. TEP working paper no. 0207. Dublin: Trinity College Dublin, Department of Economics.

Fujita, S. \& Nakajima, M. (2016). Worker flows and job flows: A quantitative investigation. Review of Economic Dynamics, 22(1):1-20.

Funlayo, O. E. (2013). The impact of economic growth on employment in Nigeria. International Business and Management, 6(1):113-119.

Gill, M. (2013). Employment and the economics of job creation. http://www.lexisnexis.co.za/pdf/Keynote-Address-Employment-the-economyandgrowth.pdf. Date of access: 09 September 2016.

Gourinchas, P. O. (1999). Exchange rates and jobs: What do we learn from job flows? In NBER Macroeconomics Annual, 13(1):153-222.

Guisinger, A. Y., Hernandez-Murillo, R., Owyang, M. \& Sinclair, T. M. (2015). A statelevel analysis of Okun's Law. FEDL Working Paper no. 2015-029A. St. Louis: Federal Reserve Bank.

Habanabakize, T. \& P. F. \& Muzindutsi, P.F. (2015). Time series analysis of interaction between aggregate expenditure and job creation in South Africa. Journal of Governance and Regulation, 4(4):649-657.

Hain, J. (2010). Comparison of common tests for normality. http://www.statistikmathematik.uni-wuerzburg.de/fileadmin/10040800.pdf. Date of access: 04 October 2016.

Haltiwanger, J., Kugler, A., Kugler, M., Micco, A. \& Pages, C. (2004). Effects of tariffs and real exchange rates on job reallocation: evidence from Latin America. The Journal of Policy Reform, 7(4):191-208.

Hendriks, J. F. (2016). Critical evaluation of possible policy options to reduce unemployment in South Africa. http://etd.uwc.ac.za/xmlui/bitstream/handle.pdf. Date of access: 08 November 2016.

Herman, E. (2011). The impact of economic growth process on employment in European Union countries. The Romanian Economic Journal, 14(42):47-67. 
Huang, H. \& Tang, Y. (2015). How did exchange rates affect employment in U.S. cities? Contemporary Economic Policy, 34(4):678-697.

Hull, K. (2009). Understanding the relationship between economic growth, employment and poverty reduction. Promoting Pro-Poor Growth: Employment, 1(1):69-94.

Irmen, A. (2005). Extensive and intensive growth in a neoclassical framework. Journal of Economic Dynamics and Control, 29(8):1427-1448.

Kakes, J. (2000). Monetary transmission in Europe: The role of financial markets and credit. Cheltenham, UK: Edward Elgar Publishing.

Kapsos, S. (2005). The employment intensity of growth: Trends and macroeconomic determinants. Working Paper 2005/12. Employment Strategy Papers. International Labour Office.

Kapsos, S. (2006). The employment intensity of growth: Trends and macroeconomic determinants. Labour markets in Asia. UK, London: Palgrave Macmillan, p.143201.

Keller, J.R. (2015). Markets, networks, and the internal allocation of human resources: How managers create value through internal hiring. http://mitsloan.mit.edu/ iwer/wp-content/uploads.pdf. Date of access: 11 September 2016.

Keynes, J. M. (1937). The general theory of employment. The Quarterly Journal of Economics, 51(2):209-223.

Kim, W. (2005). Analyses of the relationship between exchange rates and employment in Korea. Journal of Economic Development, 30(2):131-153.

Klein, M. W. \& Shambaugh, J. C. (2012). Exchange rate regimes in the modern era. MIT Press. http://www.jstor.org/stable/j.ctt5hhbcb. Date of access: 08 November 2016.

Klein, M. W., Schuh, S. \& Triest, R. K. (2002). Job creation, job destruction, and international competition: A literature review. Working Paper no. 02-7. Boston: Federal Reserve Bank.

Klein, M. W., Schuh, S. \& Triest, R. K. (2003). Job creation, job destruction, and the real exchange rate. Journal of International Economics, 59(2):239-265.

Kundu, M. G., Mishra, S. \& Khare, D. (2011). Specificity and Sensitivity of Normality Tests. https://xa.yimg.com/kq/groups/16412409/1720123946/name/ISOS_Art+01_ Kundu_pp.+14_Corrected.pdf. Date of access: 08 November 2016.

Laubscher, J. (2013). Economic growth in South Africa: a 20-year review. http://www.moneyweb.co.za/archive/economic-growth-in-south-africa-a20year-review/. Date of access: 08 November 2016.

Leshoro, T. L. (2013). Does Economic Growth Lead Employment in South Africa? Journal of Economics and Behavioural Studies, 5(6):336-345.

Lipton, D. (2013). South Africa: Facing the challenges of the global economy. https://www.imf.org/en/News/Articles/2015/09/28/04/53/sp050813. Date of access: 06 November 2016.

Liu, H., Idrees, Z., Satti, J. A. \& Nazeer, A. (2015). Exchange rate volatility and oil prices shocks. International Journal of Academic Research in Business and Social Sciences, 5(1):249-256.

Loots, E. (1998). Job creation and economic growth. South African Journal of Economics, 66(3):155-163.

Magee, L. (2013). Unit roots, cointegration, VARs and VECMs. http://socserv.mcmaster/magee.pdf. Date of access: 05 November 2016. 
Mahadea, D. \& Simson, R. (2010). The challenge of "low employment economic growth" in South Africa: 1994-2008. http://www.scielo.org.za/pdf/sajems/ v13n4/a02.pdf. Date of access: 6 April 2016.

Malakwane, C. T. (2012). Economic and social effects of unemployment in South Africa: Prospects for the future. Doctoral dissertation, Tshwane University of Technology, Pretoria.

Martins, P. \& Takeuchi, R. L. (2013). Employment in a post-2015 framework: Proposals for monitoring indicators. ODI working paper no. 1. London: Overseas Development Institute.

Mensah, M., Awunyo-Vitor, D. \& Asare-Menako, H. 2013. Exchange rate volatility and employment growth in Ghana's manufacturing sector. International Journal of Business and Social Science, 4(4):225-232.

Meyer, D. F. (2014). Job creation, a mission impossible? The South African case. Mediterranean Journal of Social Sciences, 5(16):65-77.

Michaillat, P. \& Saez, E. (2015). Aggregate demand, idle time, and unemployment. The Quarterly Journal of Economics, 130(2):507-569.

Mpofu, T. R. (2013), Real exchange rate volatility and employment growth in South Africa: The case of manufacturing! In: ECCE-USB Conference Papers, March 2013.

Mpofu, T. R. (2015). Exchange rate volatility, employment and macroeconomic dynamics in South Africa. Doctoral dissertation, University of Cape Town: Cape Town.

Mukhtar, T. \& Rasheed, S. (2010). Testing a long run relationship between exports and imports: Evidence from Pakistan. Journal of Economic Cooperation and Development, 31(1):41-58.

Mushtaq, R. (2011). Augmented Dickey Fuller Test. http://dx.doi.org/10.2139/ssrn.1911068. Date of access: 05 November 2016.

Muzindutsi P.F. \& Maepa M.M. (2014). Manufacturing production and nonagricultural employment rate in South Africa: Time series analysis. Journal of Economics and Behavioral Studies, 6 (10): 779-786.

Ngandu, S. N. (2008). Exchange rates and employment. South African Journal of Economics, 76(2):205-221.

Ngandu, S. N. (2009). The impact of exchange rate movements on employment: The economy-wide effect of a rand appreciation. Development Southern Africa, 26(1):111-129.

Nielsen, B. (2005). Analysis of co-explosive processes. UK: Nuffield College.

Niyimbanira, F. (2015). Fuel price and exchange rate dynamics in South Africa: A time series analysis, Corporate Ownership \& Control, 12(4), 185-193.

Noumbissie, F. F. \& Mongale, I. P. (2014). The impact of monetary policy on financial markets in South Africa: A VAR analysis. Journal of Economics and Behavioral Studies, 6(8):636-646.

Nucci, F. \& Pozzolo, A.F. (2010). The exchange rate, employment and hours: What firm- level data say. Journal of International Economics, 82(2):112-123.

Okun, A.M. (1962). Potential GNP, its measurement and significance. Yale University, Connecticut, US: Cowles Foundation.

Ozturk, I. (2006). Exchange rate volatility and trade: A literature survey. International Journal of Applied Econometrics and Quantitative Studies, 3(1):85-102. 
Razali, N. M. \& Wah, Y. B. (2011). Power comparisons of Shapiro-Wilk, KolmogorovSmirnov, Lilliefors and Anderson-Darling tests. Journal of Statistical Modeling and Analytics, 2(1):21-33.

Ribeiro, E. P., Corseuil, C. H., Santos, D., Furtado, P., Amorim, B., Servo, L. \& Souza, A. (2004). Trade liberalization, the exchange rate and job flows in Brazil. The Journal of Policy Reform, 7(4):209-223.

Riegler, M. (2014). The impact of uncertainty shocks on the job-finding rate and separation rate. Working Paper no. 337. London: Job Market Papers.

Rusike, G. (2016). South Africa Ratings Affirmed; Outlook Remains Negative on Weak Growth. http://cdn.bdlive.co.za/images/pdf/SArating.pdf. Date of access: 14 September 2016.

Ruxanda, G. \& Botezatu, A. (2008). Spurious regression and cointegration, numerical example of Romania's M2 money demand. Romanian Journal of Economic Forecasting, 5(3):51-62.

Saikkonen, P. \& Lüetkepohl, H. (2000). Testing for the cointegrating rank of a VAR process with an intercept. Econometric Theory, 16(03):373-406.

SARB (South African Reserve Bank). (2016). Statistics. https://www.resbank.co.za/ Research/Statistics/Pages/Statistics-Home.aspx. Date of access: 26 October 2016.

Schmid, G. (2008). Full employment in Europe: Managing labour market transitions and risks. UK: Edward Elgar Publishing Inc.

Sims, C. A. (1980). Macroeconomics and reality. Econometrica: Journal of the Econometric Society, 48(1):1-48.

Sodipe, O. A. \& Ogunrinola, O. I. (2011). Employment and economic growth nexus in Nigeria. International Journal of Business and Social Science, 2(11):232-239.

Sögner, L. \& Stiassny, A. (2000). A cross-country study on Okun's Law. Working Paper no. 13.Vienna: WU Vienna University of Economics and Business.

StatsSA (Statistics South Africa). 2016. Quarterly labour force survey: Quarter 1, 2016. Pretoria: Statistics South Africa.

Tattara, G. \& Valentini, M. (2004). Job flows, worker flows in Veneto manufacturing. 1982- 1996. Dept of Economics University of Venice "Ca'Foscari”, Nota di lavoro, 7(1):1-22.

Tjukanov, T. (2011). Gross Domestic Product as a modern-day economic indicator. https://www.theseus.fi/bitstream/handle. Date of access: 21 October 2016.

UNDP (United Nations Development Programme). (2015). Human Development Report: Work for human development. http://hdr.undp.org/sites/all/themes.pdf. Date of access: 11 September 2016.

Van der Merwe, E. \& Mollentze, S. (2010). Monetary economics in South Africa. Cape Town: Oxford University Press Southern Africa.

Vermeulen, C. (2015). Inflation, growth and employment in South Africa: Trends and trade-offs. ERSA Working Paper no. 547. Cape Town: Department of Economics.

World Bank. (2016). South Africa economic update: Seizing the window of demographic opportunity. Http://www.worldbank.org/en/country/southafrica. Date of access: 23 March 2016.

Yokoyama, I., Higa, K. \& Kawaguchi, D. (2015). The effect of exchange rate fluctuations on employment in a segmented labour market. Research Institute of Economy, Trade and Industry (RIETI). http://hias.ad.hit-u.ac.jp/wp- content/uploads.pdf. Date of access: 02 November 2016. 
Zanini, F. C., Irwin, S. H., Schnitkey, G. D. \& Sherrick, B. J. (2000). Estimating farm-level yield distributions for corn and soybeans in Illinois.

http://ageconsearch.umn.edu.pdf. Date of access: 02 November 2016. 